\title{
NOVELTY IN ARCHITECTURE AS A FACTOR OF ITS DESIGN: A CONSERVATIVE VIEW
}

\author{
Irina Bembel \\ Ph.D. in Arts \\ Author's Orcid number: 0000-0003-0876-8244
}

Senior Researcher at the Scientific Research Institute of Theory and History of Architecture and Urban Planning (NIITAG), branch of the Central Institute for Research and Design of the Ministry of Construction and Housing and Communal

Services of the Russian Federation, Moscow, Russia

\begin{abstract}
The purposeful attitude towards novelty is a relatively young phenomenon. The attitude to the New as an independent value was shaped initially in the Renaissance (or in the late Middle Ages); it lies in the same channel with the theory of progress. The phenomenon of fashion was gradually formed under its influence and involved into its orbit almost all aspects of life, including art and architecture, one or another degree.
\end{abstract}

The endless need for renewal is defined as one of the main features of modernity as a paradigm ('modern' as new, contemporary).

What is fashion as a cultural phenomenon, and why did it acquire such great importance precisely in the Modern Times - the epoch of architectural 'styles'? When does tradition become fashion? How are novelty and freedom, the two main values of the modern paradigm, related? How does the general attitude towards novelty affect the criteria for the aesthetic assessment of contemporary architecture? The category of fashion only recently has become a subject of philosophical reflection, while not affecting the sphere of architecture.

In this article, the phenomenon of the New in architecture is considered from the point of philosophical traditionalism. Another starting point of reasoning is the method of the Viennese school of art history, formulated in the phrase "History of art as the history of the spirit". The religious and philosophical context reveals a fundamentally different approach to the phenomena of novelty and freedom in tradition and modernity and deepens the understanding of the revolution that was carried out in modern architecture. Thus, it helps to substantiate S.O. Khan-Magomedov's idea of two superstyles and refutes the generally accepted point of view, according to which modern architecture directly inherits and evolutionarily develops the achievements of tradition. Taking this idea as a whole, we consider it more broadly - in the sphere of traditional and modern architecture.

Key words: phenomenon of the New, freedom, philosophical traditionalism, tradition, modern, fashion, superstyles on architecture. 


\section{INTRODUCTION}

The profound crisis of the humanities in general, and art history in particular, has been repeated regularly by various researchers in recent decades. So Hans Belting, author of a book with the meaningful title "The End of Art History"? writes: "I avoid building any 'methods' in art history. On the contrary, I am convinced that today only temporary, conditional and even fragmentary judgments and statements are possible "(Yakovleva 2010). The crisis is primarily related to the erosion of criteria: it is completely incomprehensible how to analyze the latest works in which individual authorship completely dominates, which programmatically declares the rejection of continuity, sample orientation and any consistency? "When an art historian studying the heritage of the 19th century tries to talk to the curator of a contemporary exhibition, it turns out that they do not have a common vocabulary, as if these people worked in different disciplines" (Schipkov 2013).

In this context, several new methods have emerged in Western art criticism: artistic processes are considered from the perspective of psychoanalysis, social history, structuralism, and poststructuralism. (eg the book "Art since 1900: modernism, anti-modernism, postmodernism"). Recently, another specific technique has spread: architecture is analyzed from the point of view of the theory of self-organization or synergetics (Complexity 2008). Among Russian researchers D.E. Fesenko. (Fesenko 2010). But all of them, we note, completely fit into the modernist / postmodern - ie the modern field of philosophy.

In other words, the history of architecture is considered from the point of view of contemporary paradigms. The aim of the article is to propose the opposite approach: to consider the processes taking place in architecture from the point of view of traditional paradigms.

"For millennia, man has lived an 'unhistorical' life. The traditional cultures of Africa and Asia, the disintegration of which is now coming to completion and which have become a victim of progress imposed by the West, first under the flag of colonization and then 'emancipation', - those cultures did not know any other form of existence than 'non-historical' ones", writes Germain Bazin "(Bazin 1994 : 9).

And further: "The man of the 'Middle Ages', media etu \{...\}, lived, if not outside of history, then, in any case, somewhere above it. Since the Christian in his reflections constantly returned to the original state of humanity, he did not think of himself as an active creator of history, which, in his view, is entirely in the hand of God. <...> The Christian lives only by hope, by expectation of another life. And is not the day of the death of a saint called natalis dies, that is, 'birthday'? The sphere of experience is only an epiphenomenon of the eternal, it has meaning only sub specie aeternitatis." (From the point of view of eternity) (Bazin 1994: 10).

It is no coincidence that Bazin unites the cultures of Asia, Africa, and the European Middle Ages, so distant from each other in geographical and temporal meaning. With all confessional differences, the traditional cultures were connected with a common fundamental orientation towards an ideal and eternal supersensible world, and, accordingly, assigning a 'secondary' role to earthly human existence. That attitude has given the architecture of traditional civilizations a number of fundamental unifying peculiarities, such as hierarchical ordering, the presence of a unifying centre, symmetry, specific tectonic, their own rhythm, strict orientation to the cardinal points, as well as conservatism and continuity. Traditional architectural forms carry strictly defined meanings and senses: for example, the cube in tradition symbolizes the earth, the sphere - the sky, the circle the eternity, etc. So, shaping in the tradition excludes an occasion and author's arbitrariness.

The specific modern craving for renewal, for change was clearly identified in the Renaissance for the first time. It is here that the idea of progress is rooted - "unequivocal, uniformly progressive development, which calmed the historical conscience" (Dvořák 2001: 9). In the same line, the theory of evolution arises, which Clive Lewis called the Great Myth. Theologian Lewis draws attention to the speculative, ideological nature of the theory of evolution and its consonance with the secular spirit of the times. "If science can offer any arguments in support of such an Evolution, they will be gladly accepted. If she comes up with arguments against it, they simply won't be noticed" (Lewis 1998). 
Noteworthy, in the Renaissance, a specific fashion phenomenon got emerged (although some prototypes of fashion in the modern sense also took place in Classical antiquity). Fashion is seen as nothing more than a by-product of the theory of evolution. Everything must be renewed, and if there are no objective reasons for that, then man-made forms can be arbitrarily changed. It seems that fashion can be viewed as a surrogate for the attitude towards arts and crafts that dominated in the tradition, when any human activity was "clothed with a 'sacred' and 'ritual' character in the true sense of the word" (Guénon 2011: 58).

At the same time, it would be wrong to believe that the conservatism inherent in the traditional consciousness, reflected in the stability of traditional art forms, excluded the attitude towards renewal. On the contrary, the phenomenon of novelty had been a value earlier, but it has undergone a decisive revision in the Modern Times.

In the Christian tradition, renewal is considered as a return to the paradise state, the original norm of the primordial creation, lost as a result of the Fall. Hence, the image of the New (renewed) Adam in Christianity, as opposed to the 'Old' (sinned) Adam; new creature, new heaven, and new earth at the end of times (Apocalypse). Renewal was considered as restoring the original dignity.

In harmony with this attitude, the forms of traditional architecture are saturated with symbols of paradise, heaven, Heavenly Jerusalem, etc. The stability of these forms corresponds to the inviolability of their symbolic meaning. The infinity of the path to absolute perfection was a guarantee of the infinity of renewal and the inexhaustibility of the resource of novelty in the tradition. The 'Great Book of God' about which Gregory the Theologian writes (Gregory 2007: 132) can never be read to the end. The mimetic approach as comprehending the principles of creation through contemplation of nature and regulating the internal 'tuning fork' to invisible, supersensible perfection were the means that prevented the absolutization of the literal reading the canon to the detriment of the spirit of living creativity.

During the Renaissance, the situation changed: an intense secular restructuring was started. It became a symptom of the depletion of that internal resource of renewal, which was fed with the mental contemplation of 'eidos' and 'prototypes'. Germain Bazin seems to be the first to draw attention to a strange paradox: the Renaissance as an actual return to the Classical antiquity, i.e. to the 'old', is considered a new turn in art, while the Gothic, which made a real breakthrough in shaping, is referred to as the 'old', the overcome medieval form.

Since Bazin does not give his own explanation of this peculiarity of perception of the history of architecture, but only casually denotes it, it is worth dwelling on it in more detail. From our point of view, this imaginary paradox is explained precisely with the radically changed attitude towards the phenomenon of novelty. From now on, novelty becomes a predominantly external factor and is gradually identified with simple variability, which becomes an independent value.

Opposite to the endlessness process of renewal in tradition - renewal as an integral transformation that organically entails a change in form, the resource of external variability is limited. Variability operates only with existing material forms, either through their repetition, or through their deconstruction (anti-forms).

The architecture took the first path during the Modern Times, when ready-made historical forms, mainly order ones, were adapted to some new content. There is a tangible parallel with the process taking place in the late Classical architecture: the process of its 'Christianization', "a long process of merging and assimilation of old Classical and new Christian elements" (Dvorák 2001: 8), although the direction of these processes was mutually opposite. During the Renaissance, the process of de-Christianization of architecture begins. Against the background of the weakening of the general spiritual vector, there is an increase in external decorativeness.

The essence of the transformation is shrewdly revealed by August Shmarzov: "A historian, who has followed with awe and amazement the majestic tread of the art of construction through the millennia, may seem that at some point in his zealous efforts directed at certain forms, styles and tasks of the past they have lost a certain spiritual hoop, pulling together all parts of the whole and all means for the sake of a single goal." (Shmarzov). 
In the Modern Times, there was a growing tendency to rigidly enforce regulations. With the weakening of the common connecting religious idea ('centre', according Zedlmayr), technical means began to acquire an increasing importance. Mathematical calculations of the laws of beauty gradually overshadowed the inner striving for its invisible supersensible source. One after another, the Academies of Arts opened in Europe: Bologna (1585), French (1648), St. Petersburg (1757), and others, strictly oriented to the canons of the order architecture. At the same time, the sacred genesis of old forms came into growing conflict with new secular ideas and functions. Academic excellence essentially boiled down to solid, but completely 'external' craft training based on studying historical styles, and the meaningful emptiness of desacralized forms was 'compensated' with the increasing splendor of the decor. This fact is clearly illustrated with the monument to Victor Emmanuel in Rome, the Grand Opera in Paris, and a number of other similar characteristic structures.

By the end of the nineteenth century, architecture had actually exhausted its resource of renewal through borrowing old forms. Self-repetition, refinement of forms, and the general decline of architecture during the period of Eclectic stimulated an intense search for new ways.

The phenomenon of Freedom is closely connected with the phenomenon of the New. Its perception is as fundamentally different in tradition and modernity as the perception of novelty.

In the paradigm of tradition, freedom is invariably associated with the need of an individual for selfrestraint, that goes back to the original prohibition to eat from the Tree of Knowledge and the Ten Commandments. In fact, the entire culture of the tradition was built on a system of prohibitions and taboos. In one of his letters, Plato writes: "Both obedience and freedom, if they overstep boundaries, are the greatest evil, in due measure, this is a great blessing: slavish obedience to the gods is normal, but to people it is not normal. For rational people, God is law, for unreasonable people pleasure" (Plato 1999: 507). Thus, freedom is the ability to choose, which presupposes selfrestraint for the sake of truth.

In Christianity, freedom is also associated with moral choice. "If ye continue in my word, then are ye my disciples indeed; And ye shall know the truth, and the truth shall make you free" (John 8: 3132). "Whosoever committeth $\sin$ is the servant of $\sin .$. . If the Son therefore shall make you free, ye shall be free indeed" (John 8: 34-36). Thus, in tradition, the path to freedom is associated with the knowledge of the truth. Deviation from the truth, on the contrary, plunges into the bondage to sin.

The principle of voluntary self-belittling for the sake of truth is associated with the submission to the established canons inherent in traditional art, as well as anonymity as the norm. On the one hand, this ensures the ontological truthfulness of art, on the other hand, it frees the artist from the need to repeat each time the same lessons (Florensky 1985: 235-236).

\section{RENOVATION THROUGH THE DENIAL OF THE 'OLD'}

The Modernist revolution marked the entry of architecture on the second path - the path to renewal through negation and deconstruction of traditional forms. On that way, architecture has developed appropriate symbolism and a radically new language, which S.O. Khan-Magomedov reasonably called 'the second superstyle' (Khan-Magomedov 2010: 8). Shaping of the second superstyle was radically different, in comparison with tradition; its worldview was based on the ideas of materialism and progress. Its essential (and not externally decorative) novelty is confirmed with a new unity of form, function, and structure, a unity that uses new possibilities of contemporary materials and technologies.

The attitude towards the 'new aesthetics' and the insistent apology for the 'new beauty' virtually ruled out the question of a qualitative comparison of the two superstyles. However, the general crisis of Modernism at the end of 1960s still shaken blind faith in the truth of the path followed by modern architecture. In addition, if, at the origins of Modernism, architecture served a certain (social) goal, and its path seemed straight and clear, in the last quarter of the twentieth century, after disappointment in the ideas of Marxism and postmodern philosophical revision, the situation changed. In the conditions of the market, the demands of originality have replaced the previous attitudes towards beauty and then towards functionality. Only one (anti-)landmark remained un- 
shakable - traditional architecture as an object of denial and overcoming. The denial of tradition as a systemic integrity is the main and, in fact, the only unifying feature for the kaleidoscopic set of the latest trends in the second superstyle. Obviously, it is precisely because of this that 'anti-forms' have an amazing property to look 'modern', regardless of the age of certain specific techniques (for example, a console that is strongly brought forward or non-equilibrium compositions of simple geometric figures characteristic of the avant-garde of 1920s).

If the 'old' is brought to the surface by the latest architecture, it is only fragmentary and unsystematic, either for its inventive deconstruction, or for an ironic-parodic quotation.

Reference can be made to the numerous examples of projects published daily by the popular architecture website www.archdaily.com as the best ones.

It is easy to observe, both ways of achieving novelty, proposed by the Modern and the Contemporary Times, are 'secondary', and they are directly dependent on the baggage that is 'collected' by tradition. In other words, without the arsenal of these achievements, the Modern Time would have nothing to repeat, and the Contemporary Time - nothing to refute and destroy.

The influence of the theories of progress and evolution, as well as the phenomenon of fashion, fully affected the perception of conservative phenomena in architecture, painting, and other arts of the Contemporary Time. Almost all of them are outside the field of vision of today's leading critics and art specialists, who, like frogs and crustaceans, perceive only moving objects. Neoclassicists in architecture and realists in painting remain marginal. They simply 'don't exist' on the map of the great history of art, except those cases when conservative phenomena become, for a short moment, elements of fashion, undergoing an absurd and/or ironic Postmodern transformation. The same mechanism works, which were discovered by Clive Lewis in relation to science.

Nowadays, the orientation towards novelty and freedom from tradition inevitably turns into new types of addiction. One of them is the 'duty' of modern architects to be original. At the same time, the orientation towards originality inevitably comes into conflict with the requirements of expediency, convenience, saving resources, etc.

To solve this problem and for the sake of development of the process of total regulation, launched in the Modern Time, there is a continuous growth of the existing standards in the field of design and construction. Much of what was previously transmitted orally, which was implied for reasons of common sense, decency, and general stable ideas about beauty and order, now becomes the subject of precise and thorough regulations. Among others, it becomes one of the evidences of the loss of the 'internal law' ('commendation') written 'in fleshy tables of the heart' (2 Cor. 3:3), as well as the general 'hardening of the world', about which Rene Guenon writes (Guénon 2011: 120).

As a result, having broken with aesthetic canons and traditions, the architect found himself bound hand and foot by the requirement of originality, on the one hand, and a growing number of often contradictory utilitarian standards, on the other.

Thus, the empirical approach, rejecting metaphysics, provides an argument in favor of the Gospel understanding of freedom: belittling oneself before the truth raises and liberates (the old art), and 'independence' from it and the emancipation of one's ego, on the contrary, belittles and enslaves, both in the highest metaphysical sense, and in the specific worldly sense.

\section{DIGITALIZATION AND NOVELTY}

In the wake of total digitalization, the criterion of novelty received a powerful additional impetus. As design is increasingly delegated to the computer, and technology is rapidly developing, the resource of architectural novelty promises to be inexhaustible. In this inverted semblance of the traditional inexhaustibility of the divine source of beauty, it is easy to see one of the manifestations of "the great parody or spirituality inside out", which Rene Guenon writes about (Guénon 2011: 284). "It can be noted that a machine is in a sense the opposite of an instrument, and is not at all an 'improved' instrument, as many imagine, since an instrument is a kind of 'continuation' of a person 
himself, while a machine turns a person into nothing more than its servant; and if it could be said that 'an instrument gives rise to a craft', it is equally true that a machine kills it" (Guénon 2011: 63).

Computer design (i.e., in essence, calculations) finally removes the issue of quality assessment, aesthetic criteria in the traditional sense. It means another transformation of the criterion of novelty: it is no longer determined by external aesthetics, not functional qualities, and not even a conscious protest against the 'old' beauty, but arbitrary, not associated with logical thinking and to a certain extent unpredictable for a person (co-author of a machine) variability of digital technical forms.

At the same time, 'commonness', i.e. the norm is still 'necessary' for contemporary architecture as an initial tuning fork and unshakable concept, since if there is no norm, then there is no originality either. This is confirmed with the fact that modern buildings look especially impressive in the prevailing historical environment, while traditional architecture is completely self-sufficient.

The denial of the 'old' and total digitalization as the main principles of contemporary architecture and modernity, in general, concern among representatives of various professions, but due to the same mechanism that Clive Lewis wrote about, the world establishment prefers 'to ignore' them. Reforms of architectural education are also aimed at digitalization, consolidating the modern vector of development, and replacing 'hotbeds of resistance' in the form of classical architectural schools.

The transition "from education to o-programming" is called the goal of reforms in education by philosopher V.A. Kutyrev. "E-learning supplemented with gadgetism leads away from understanding what is happening in the objective world and leads to leaving it altogether. <...> Virtualization of education is zombification of new generations, a condition and forerunner of their robotization" ( $K u$ tyrev, Slyusarev, Khusyanov 2020: 243). This fully applies to architectural education, the innovation system of which actually becomes a programming system.
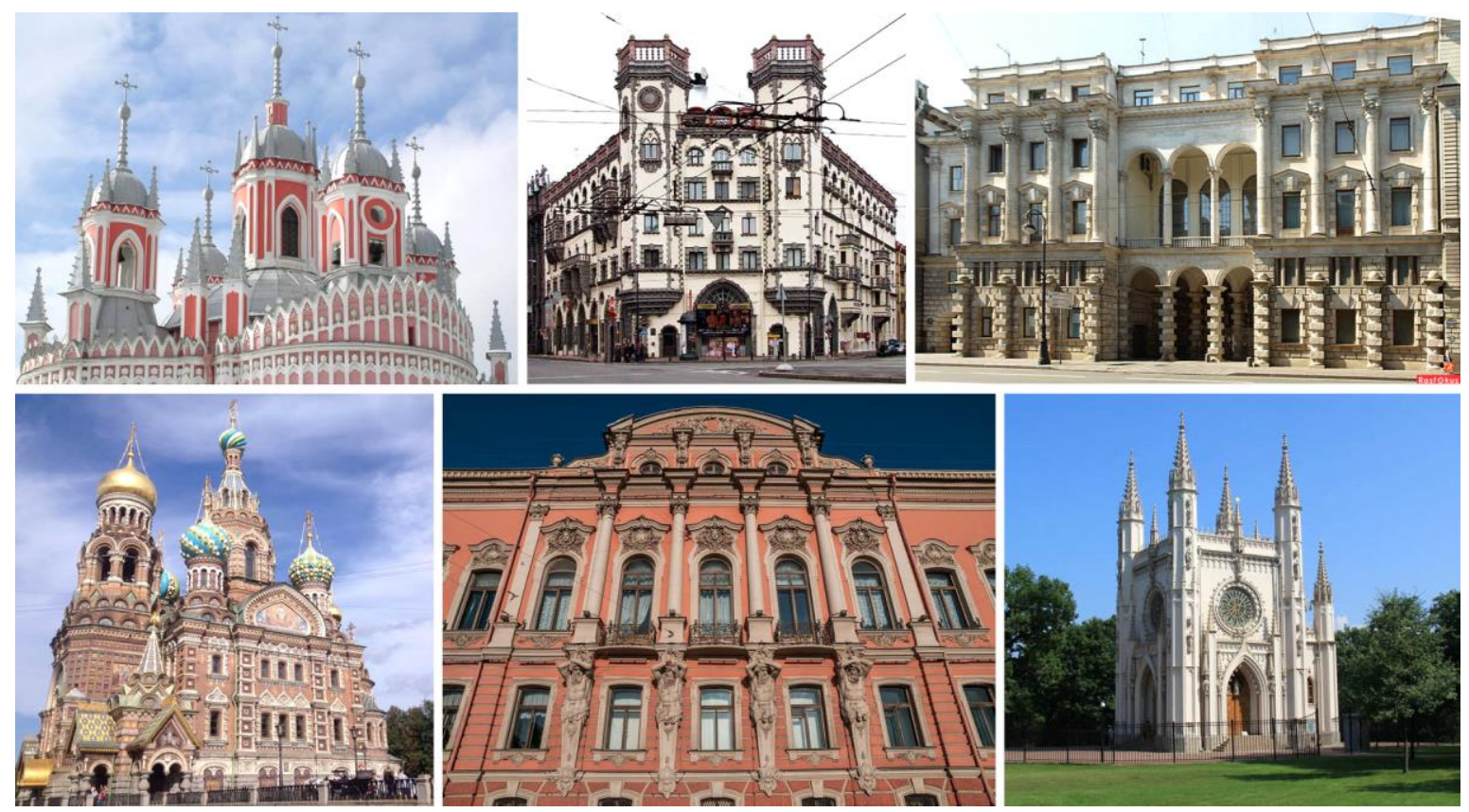

Fig. 1. Update by duplicating "old" ones. Examples of historicism in the architecture of St. Petersburg in the nineteenth century. The cited examples illustrate the formal style of their era. Source: Photos of the Author and from free Internet resources

The need to refer to the 'old' as a source of sustainable design algorithms is proved by the mathematician and theorist of architecture Nikos Salingaros. In his works, consistently, relying on scientific achievements in the field of physics, mathematics, psychology, visual perception, as well as architectural theory and practice, the principles of New Urbanism (which in fact is a return to the 
principles of old urbanism) are defended (Salingaros 2017; Salingaros 2019 ; Salingaros, Brain, Duany, Mehaffy, Philibert-Petit 2019).

The global crisis phenomena of the last century clearly indicate the danger of the 'modern' path of renewal. At the same time, it must be recognized that in the architectural world this kind of concern is rather an exception to the rule. In the latter circumstance, the fruits of 'zombification' and the implanted cult of novelty and modernity are fully reflected.
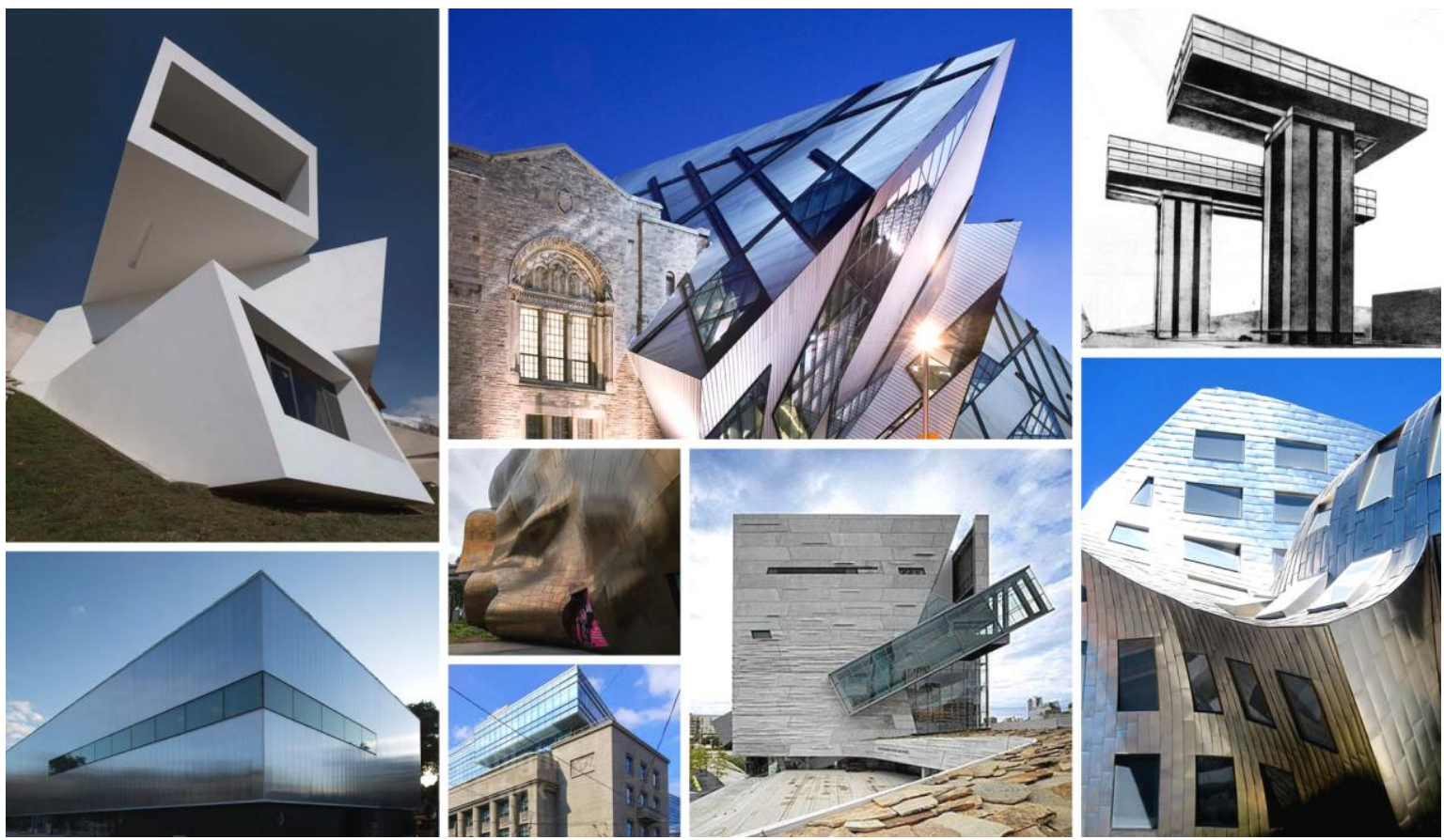

Fig. 2. Renewal by discarding the "old". Commonly known examples of Soviet, Russian and world architecture. Source: Photos of the Author and from free Internet resources

\section{CONCLUSION}

The analysis of historical changes in relation to the phenomenon of the New deepens the understanding of the revolution that was carried out in modern architecture. A change in form as a consequence of an internal renewal in tradition, a change in form as an external reproduction of the 'old' in the period of Historicism, and, finally, a change as a clear overcoming of the 'old' in the Modern Time, these fundamental changes in the perception of the phenomenon of novelty became one of decisive factors that predetermined the transition architecture from the first superstyle to the second one.

Evidently, the reasoning given here is only an extremely generalized scheme. The real situation includes many multidirectional tendencies, including those associated with the resistance of the 'old' that stretched out for centuries, as well as with individual manifestations of great talent and, moreover, genius, which, as a rule, is outside the mainstream.

These circumstances, however, do not negate the presence of fundamental general patterns in the development of architectural shaping, which go beyond the framework of historical styles in the Wölflin's understanding, and are associated, first of all, with the transformation of values. The identification of these large regularities seems to us to be the most important task of contemporary art history, which is experiencing a systemic methodological crisis.

A conservative approach to the principles of art and phenomenology is also applicable today in architecture, where aesthetics is only one important aspect. 


\section{BIBLIOGRAPHY}

Bazin G. Istoriya istorii iskusstva: Ot Vazari do nashikh dney (The History of Art History: from Vasari to the Present). Ed. Ts. Arzakanyan. Moscow: Progress - Kultura Publ., 1994 (in Russian).

Bembel I. O. My dolzhny vse nachat s nulya: Intervyu s Nikosom Salingarosom (We must begin from the ground up: Interview with Nikos Salingaros). URL: http://aaaunion.ru/diskurs/nikosinterv/. Accessed on 01.09.2020 (in Russian).

Bembel I. O. Ob esteticheskikh kriteriyakh v kontekste antagonizma dvukh superstiley (About aesthetical criteria in the scope of antagonism of the two superstyles). Arkhitektura $i$ stroitelstvo Rossii, 2020, no. 2 (234) (in Russian).

Complexity. Design Strategy and World View. Edited by A.Gleiniger and G.Vrachliotis. - Birkhauser, Basel Boston - Berlin, 2008.

Dvořak M. Istoriya iskusstva kak istoriya dukha (The History of Art as the History of Ideas). Ed. A. Lepork. Saint Petersburg: Akademicheskiy proyekt Publ., 2001 (in Russian).

Fesenko D.E. - Teoria arkhitekturnogo protsessa: kontury novoj paradigmy - M.: Arkhitekturnyj vestnik, 2010. - URL: http://www.intelros.ru/subject/figures/teoriy_arh_processa/6764-teoriya-arxitekturnogoprocessa-kak-narozhdayushhayasya-disciplina.html

Florenskiy P. A. Ikonostas (Iconostasis). Florenskiy P. A. Sobraniye sochineniy (Collected works). Vol. 1. Statyi po iskusstvu (Articles on Art). Ed. N. A. Struve. Paris: YMCA-press Publ., 1985 (in Russian).

Gregory the Theologian. Slovo 6 (Homily 6). Gregory the Theologian. Tvoreniya (Works). Vol. 1. Slova (Homilies). Ed. Metropolitan of Tashkent and Central Asia Vladimir. Moscow: Sibirskaya blagozvonnitsa Publ., 2007 (in Russian).

Guénon R. Tsarstvo kolichestva i znameniya vremeni (The Reign of Quantity \& the Signs of the Times, 1945). Moscow: Belovodye Publ., 2011 (in Russian).

Khan-Magomedov S. O. Ivan Zholtovskiy (Ivan Zholtovskiy). Moscow: S. E. Gordeyev Publ., 2010 (in Russian).

Kutyrev V. A., Slyusarev V. V., Khusyainov T. M. Chelovechestvo i Tekhnos: filosofiya koevolyutsii (Humanity and technos: the philosophy of coevolution). Saint Petersburg: Aleteyya Publ., 2020 (in Russian).

Lewis C. Pokhorony velikogo mifa (The funeral of a great myth). URL: https://www.scienceandapologetics.com/stati/503-pohorony-velikogo-mifa.html. Accessed on 24.08.2020 (in Russian).

Plato. Zakony (The Laws). Ed. A. F. Losev, V. F. Asmus, A. A. Takho-Godi. Moscow: Mysl Publ., 1999 (in Russian).

Perelom. sbornik statej o spravedlivosti traditsii. Red. A.V. Schipkov, 2013. URL:

https://mir-knig.com/read 223821-15

Salingaros N. A. Algoritmy ustoychivogo proyektirovaniya (Algorithmic Sustainable Design). Moscow - Yekaterinburg: Kabinetnyy ucheniy Publ., 2019 (in Russian).

Salingaros N. A. Anti-arkhitektura i dekonstruktsiya. Triumf nigilizma (Anti-Architecture and Deconstruction. The Triumph of Nihilism. Moscow - Yekaterinburg: Kabinetnyy ucheniy Publ., 2017 (in Russian).

Salingaros N., Brain D., Duany A. M., Mehaffy M. W., Philibert-Petit E. Socially-Organized Housing: Biophilia, Connectivity, and Spirituality. URL: https://www.archdaily.com/922149/socially-organized-housingbiophilia-connectivity-and-spirituality/. Accessed on 17.03.2020.

Sedlmayr H. Utrata serediny (Art in Crisis, the Lost Center, 1958), Moscow: Progress-traditsiya Publ., 2008 (in Russian).

Yakovleva O.I. Teoriya Hansa Beltinga v ego rabote «Konets istorii iskusstva?» / Vestnik MGOU, №3, 2010, p. 219 (in Russian).

\section{AUTHOR'S NOTE}

Ph.D. of Art History / Chief Editor of the "Kapitel" magazine (St. Petersburg, Russia) / Senior researcher of the Scientific Research Institute of Theory and History of Architecture and Urban Planning, branch of the Central Institute for Research and Design of the Ministry of Construction and Housing and Communal Services of the Russian Federation (NIITIAG) 